\title{
Community-oriented Primary Care Services Model: Can it improve Morbidity Status in India? An Impact Evaluation Study
}

\author{
${ }^{1}$ Sanjeev Davey, ${ }^{2}$ Pradeep K Kapoor, ${ }^{3}$ Meenu Bala, ${ }^{4}$ Jai V Singh, ${ }^{5}$ Santosh K Raghav, ${ }^{6}$ Nirankar Singh
}

\begin{abstract}
Introduction: The community-oriented primary care (COPC) services model is an approach prescribed by the Medical Council of India for existing medical colleges in India from their respective urban and rural health training centers (RHTCs). However, the evidence of whether it is better as compared with pure primary health care approach in the Indian context is lacking in the literature. Therefore, it becomes imperative to study this area for its further expansion.
\end{abstract}

Materials and methods: The study was done in the catchment area of RHTC and neighboring primary health center (PHC; Makhiyali) attached to the medical college in the district of Western Uttar Pradesh in India. Three surveyed villages out of six villages from July 1, 2016, to December 31, 2016, were taken in this study. Finally, the COPC vs primary health care approach comparison was done on four outcome parameters.

Results: The utilization of COPC services from RHTC area as compared with primary health care services from $\mathrm{PHC}$ area was significantly better for all diseases combined $(p<0.005)$ and also in the category of management of upper respiratory tract infections $(p<0.0001)$ and nutritional deficiencies $(p<0.05)$. On further applying COPC services model, it was also found that RHTC services were significantly better as compared with $\mathrm{PHC}$ services in terms of socioeconomic impact on health from services $(p<0.0000)$, identification of health needs from services $(p<0.0000)$, and participation in health care services $(p<0.05)$.

Conclusion: The COPC services model appears to be successful in the delivery of health care services from RHTC of a medical college as compared with pure primary health care approach delivered from a PHC. However, authors suggest more in-depth multicentric studies on this issue before generalization of COPD model usage across the world.

Keywords: Community-oriented primary care, Primary health care, Primary health center, Rural area, Rural health training center.

How to cite this article: Davey S, Kapoor PK, Bala M, Singh JV, Raghav SK, Singh N. Community-oriented Primary Care

\footnotetext{
${ }^{1,2}$ Associate Professor, ${ }^{3}$ Ex-Medical Officer, ${ }^{4}$ Professor and Head ${ }^{5}$ Lecturer and Statistician, ${ }^{6}$ Professor

1-6Department of Community Medicine, Muzaffarnagar Medical College, Muzaffarnagar, Uttar Pradesh, India
}

Corresponding Author: Sanjeev Davey, Associate Professor Department of Community Medicine, Muzaffarnagar Medical College, Muzaffarnagar, Uttar Pradesh, India, Phone: +9101127555172, e-mail: sanjeevdavey333@gmail.com
Services Model: Can it improve Morbidity Status in India? An Impact Evaluation Study. Int J Res Foundation Hosp Healthc Adm 2017;5(1):8-14.

Source of support: Nil

Conflict of interest: None

\section{INTRODUCTION}

The Declaration of Alma-Ata (1978) defines primary health care as "an essential health care based on practical, scientifically sound and socially acceptable methods and technology made universally accessible to individuals and families in the community through their full participation and at a cost that the community and country can afford to maintain at every stage of their development in the spirit of self-reliance and self-determination"1,2

The community-oriented policy is a strategy of policy that focuses on policy building ties and working closely with members of the communities. The communityoriented primary care (COPC) service model is based on community-oriented policy in which a local health system takes responsibility for the health of an identified community and in collaboration with the community, it identifies the public and personal health problems facing the community, develops and implements communityappropriate public and personal health care interventions, measures the impact of the intervention, and corrects plans and actions based on lessons learned. ${ }^{1,2}$ This policy has served as an impetus for the development of the community health center programs in many developed countries. ${ }^{1,2}$

The COPC is a comprehensive approach to care for community members, which not only considers the socioeconomic and cultural determinants of health but also identifies health needs and provides health care to the total community. ${ }^{3}$

Nowadays, globally, primary care is gaining importance because it is the component of health services that tackles most of the health problems arising in a community, and when enhanced by a community orientation, it is a public health at the local level. ${ }^{4,5}$

Community-oriented primary care actually combines elements of clinical medicine and public health to provide 
an effective strategy for tackling today's health problems. A primary care practice or program that develops a partnership with an identified community to describe and prioritize health concerns and design and monitor the impact of an intervention can make a difference to the health of a community. The key ingredient to a successful COPC venture is a motivated practitioner ${ }^{6}$ and community-based participatory research (CBPR) practice that has emerged to bridge the gap between research and primary care practice through community engagement and social action to increase health equity. ${ }^{7}$

It has been evident from the literature that many factors influence morbidity patterns in rural areas as catered by a health center or hospital, such as demographic, social, household, and economic. ${ }^{8-11}$ Studies conducted in different states of India ${ }^{12-17}$ also indicate that the case rate is higher not only for the 18 to 45 years age group but also for preschool children, adolescents, and the elderly in rural areas. ${ }^{18}$ Moreover, it has been seen that factors, such as cleanliness of the premises, face-lift, and clean toilet with privacy and availability of safe drinking water facilities can improve client satisfaction in rural health care delivery systems. ${ }^{19}$ This kind of scenario places a question mark on quality services from existing primary health care strategy.

The Medical Council of India ${ }^{20}$ recognizing this aspect in its regulation has emphasized that every medical college must have three primary health centers/rural health training centers (RHTCs) for training of students in community-oriented primary health care and rural-based health education for the rural community attached to it.

It has been evident from the literature that COPC service model can give us the tools to combine preventive, promotive, and curative approaches by focusing our efforts on a defined community and prioritizing the issues as seen from many studies. ${ }^{1-7,21}$ So, the question is whether COPC is a better approach as compared with pure primary care health care approach in the Indian context - this aspect is not evident from the literature. Therefore, the key objective of this study is to know the impact of applying COPC services model on disease status in a rural area of India. This is the reason why the authors choose this research area.

\section{MATERIALS AND METHODS}

Our study is a comparative cross-sectional study which includes all kinds of patients from infants to adults and the elderly conducted from July 1, 2016, to December 31, 2016 (6 months) at a RHTC catchment area in three surveyed villages (Bilaspur, Shernagar, Dhandedha) out of total six villages catered (Bilaspur, Shernagar, Makhiyali, Dhandedha, Bhagwanpuri, and Sikhreda) by the RHTC. Here, the COPC services were delivered and its comparison was done with primary health care services given from neighboring block primary health center (PHC) which also catered to the same villages as catered by the RHTC. All surveyed population of three villages (Bilaspur, Shernagar, Dhandedha) were considered in this study.

First of all, after noting the sociodemographic data from survey, the morbidity pattern of the area was seen by physically verifying various morbidities in the field by researchers. Thereafter, the comparison of disease patients who were provided COPC services from RHTC and primary health care services from PHC was done regarding their services availed for their respective diseases. Finally, COPC services model parameters were taken for comparison among RHTC and PHC services.

The inclusion criteria adopted in this study included all types of subjects from infants to adults and elderly from any sex, caste, and religion who were willing to participate in giving responses from RHTC and PHC area of three surveyed villages (Bilaspur, Shernagar, Dhandedha).

The comparison parameters considered in COPC service model were based on the studies of Rhyne et al and Longlett et $\mathrm{al}^{22-23}$ in which they have elucidated that COPC is a systematic approach to health care based on principles derived from epidemiology, primary care, preventive medicine, and health promotion. Keeping in view this model, the services from both RHTC and PHC were compared following issues after making sociodemographic parameters of the community and making a community diagnosis: (1) Developing and implementing interventions in the form of all kinds of services given at RHTC or PHC, (2) monitoring the impact of the interventions, and (3) involving the community to carry out the previous steps.

The key parameters used for comparison in our study were number of patients received from communityoriented primary care services from RHTC vs Number of patients received from primary health care services by PHC. The cross comparisons were done on two issues, i.e., number of patients satisfied with primary health care services by PHC vs number of patients satisfied from COPC services from RHTC on four parameters: (1) Socioeconomic impact on health from services as reflected by their better financial and health status after procuring services from either RHTC or PHC, (2) cultural determinants of health identified from services based on their sociocultural aspects identified and fulfilled for their health status after getting services from either RHTC or PHC, (3) identification of health needs from services whether they were satisfied on their health needs 
Table 1: Sociodemographic profile of catered and surveyed population in RHTC [N=26,300]

\begin{tabular}{lllllll}
\hline $\begin{array}{l}\text { Name of } \\
\text { village }\end{array}$ & $\begin{array}{l}\text { Population } \\
\text { of village }\end{array}$ & $\begin{array}{l}\text { No of families } \\
\text { surveyed }\end{array}$ & $\begin{array}{l}\text { No and } \% \\
\text { of adults } \\
\text { surveyed }\end{array}$ & $\begin{array}{l}\text { No and \% of } \\
\text { adolescents } \\
\text { surveyed }\end{array}$ & $\begin{array}{l}\text { No and \% children } \\
\text { under 5 years } \\
\text { surveyed }\end{array}$ & $\begin{array}{l}\text { No \& \% } \\
\text { of elderly } \\
\text { surveyed }\end{array}$ \\
\hline $\begin{array}{l}\text { Dhandedha } \\
\text { Bilaspur }\end{array}$ & 10,050 & 175 & 136 & 19 & 13 & 08 \\
Shernagar & 8,142 & 1323 & 5627 & 1902 & 104 & 509 \\
\hline Total & 8,108 & 1843 & 7356 & 60 & 124 & 568 \\
\hline
\end{tabular}

Table 2: Morbidity profile of catered population in $\mathrm{RHTC}$ area $[\mathrm{N}=26,300]$

\begin{tabular}{llll}
\hline Name of village & Population of village & No of families surveyed & $\begin{array}{l}\text { No \& \% of cases (any } \\
\text { morbid condition) }\end{array}$ \\
\hline Dhandedha & 10050 & 175 (ongoing) & $76(0.7)$ \\
Bilaspur & 8142 & 1323 & $510(6.2)$ \\
Shernagar & 8108 & 1843 & $539(6.6)$ \\
\hline Total & 26,300 & 3,341 & $1,125(3.1)$ \\
\hline
\end{tabular}

identification services from either RHTC or PHC, and (4) participation in health care services based on their participation in health days and health camp services availed.

The exclusion criteria were adopted to exclude the mortality data of three surveyed villages (Bilaspur, Shernagar, Dhandedha) due to the choice of research objective considered in the study.

\section{RESULTS}

Out of the 43,261 population catered by RHTC and PHC area, $7.7 \%$ of families were surveyed and out of them, $30.3 \%$ adults, $4.5 \%$ adolescents, $2.5 \%$ elderly, and $0.5 \%$ under 5 years children were surveyed in RHTC area and confirmed also by the PHC medical officer as part of the COPC services provided to the catered population of RHTC and PHC area (Table 1).

The prevalence of any morbid condition in total was $2.6 \%$ from the whole population, whereas the family-wise prevalence of any morbid condition was $33.7 \%$, which was higher from population residing in village Shernagar $(47.9 \%)$ and only $6.7 \%$ till the completion of this study (Table 2). The Shernagar village had maximum diseases morbidity of $6.6 \%$ and village Dhandhera had least morbidity of $0.7 \%$ in our surveyed area (Table 2 ).

When sociodemographic data of three surveyed villages of RHTC were taken, the maximum people belonged to 20 to 40 years age group (56.1\%) as compared with elderly age group $(1.7 \%)$, with more males $(51.6 \%)$, with a predominant Muslim population (52.5\%); the literates were $55.8 \%$ and backward castes [scheduled caste (SC)/ scheduled tribe (ST)+ other backward class (OBC)] were only $21.6 \%$ (Table 3 ).

The morbidity pattern of primary care diseases in RHTC and PHC area was dominated by upper respiratory
Table 3: Sociodemographic profile of patients in surveyed area of RHTC [N = 1125]

\begin{tabular}{lll}
\hline & No. & $\%$ \\
\hline Age groups (in years) & 134 & 11.9 \\
$0-20$ & 631 & 56.1 \\
$20-40$ & 341 & 30.3 \\
$40-60$ & 19 & 1.7 \\
$>60$ & 1,125 & 100 \\
Total & & \\
Sex & 545 & 48.4 \\
Female & 580 & 51.6 \\
Male & 1,125 & 100 \\
Total & & \\
Religion & 489 & 43.5 \\
Hindu & 591 & 52.5 \\
Muslim & 45 & 4.0 \\
Others & 1,125 & 100 \\
Total & & \\
Literacy status & 498 & 44.2 \\
Illiterate & 627 & 55.8 \\
Literate & 1,125 & 100 \\
Total & & 10.5 \\
Caste & 118 & 11.1 \\
SC/ST & 125 & 78.4 \\
OBC & 882 & 100 \\
General & 1,125 & \\
Total & & \\
\hline
\end{tabular}

infections (26.1\%), fever (14.8\%), and least were diabetes $(0.2 \%)$ (Table 4$)$.

When comparison of diseases was done for health services availed, it was found it in majority of diseases patients availed COPC services from RHTC as compared with primary health care services from $\mathrm{PHC}$, and this was statistically significant for morbid conditions of upper respiratory tract infections (URTI; $\mathrm{p}<0.0001$ ) and management of nutritional deficiencies $(\mathrm{p}<0.05)$, and for all 
Table 4: Morbidity pattern of primary care diseases in $\mathrm{RHTC}$ and $\mathrm{PHC}$ area

\begin{tabular}{lll}
\hline Type of disease & $\begin{array}{l}\text { No of cases } \\
(n=781)\end{array}$ & $\begin{array}{l}\% \text { of } \\
\text { cases }\end{array}$ \\
\hline URTI & 204 & 26.1 \\
Fever (clinical malaria+ typhoid) & 116 & 14.8 \\
Scabies & 73 & 9.3 \\
Gastroenteritis (incl gastritis) & 58 & 7.4 \\
Injuries (incl infected wounds) & 55 & 7.0 \\
LRTI & 44 & 5.9 \\
Allergic RTI & 45 & 5.8 \\
Skin ailments (fungal) & 34 & 4.3 \\
Dermatitis (incl acne) & 34 & 4.3 \\
Diarrhea/dysentery & 33 & 4.2 \\
Sinusitis & 24 & 3.0 \\
Undernutrition (PEM) & 22 & 2.8 \\
Ophthalmic keratitis & 10 & 1.3 \\
Abscess & 10 & 1.3 \\
Female RTI and STls & 10 & 0.9 \\
UTI & 07 & 0.6 \\
Diabetics & 02 & 0.2 \\
\hline Total & 781 & 100 \\
\hline
\end{tabular}

LRTI: Lower respiratory tract infection; PEM: Protein-energy malnutrition; RTI: Reproductive tract infection; STI: Sexually transmitted infection; UTI: Urinary tract infection

the diseases differences were also statistically significant $(\mathrm{p}<0.005)$ (Table 5).

When the outcome of applying COPC services model was seen, it was found that RHTC services were significantly better as compared with PHC services in terms of socioeconomic impact on health from services $(p<0.0000)$, identification of health needs from services $(\mathrm{p}<0.0000)$, participation in health care services $(\mathrm{p}<0.05)$ except in the issue of cultural determinants of health identified $(\mathrm{p}>0.05)$ (Table 6).

\section{DISCUSSION}

The literature reveals that CBPR approaches can increase access to care by building relationships with community partners that can determine geographical areas of need, establish community priorities for health concerns, and ultimately create a more efficient and streamlined health care delivery system. ${ }^{7}$ The CBPR is one of the ways to design sustainable community-specific interventions with the potential to produce specific improvements in several chronic conditions. ${ }^{7}$ With this background, our study also revealed some similar types of issues as evident from our study results.

In our present study, out of the 43,261 population catered by RHTC and PHC area, 7.7\% of families were surveyed. The prevalence of any morbid condition in surveyed area was $2.6 \%$ from the whole population, whereas the family-wise prevalence of any morbid condition was $33.7 \%$, which was higher from population residing in Shernagar village $(47.9 \%)$ and Dhandhera village had least morbidity of $6.7 \%$. The higher morbidities found in

Table 5: Comparison of patients with diseases who were provided COPC services from RHTC and Primary health care services from $\mathrm{PHC}[\mathrm{N}=781]$

\begin{tabular}{|c|c|c|c|c|c|}
\hline \multirow[b]{2}{*}{ Total types of diseases } & \multicolumn{2}{|c|}{$\begin{array}{l}\text { No. of patients who received } \\
\text { COPC services from RHTC } \\
(n=329)\end{array}$} & \multicolumn{2}{|c|}{$\begin{array}{l}\text { No. of patients who } \\
\text { received primary health } \\
\text { care by } P H C(n=199)\end{array}$} & \multirow[b]{2}{*}{ Chi-square test } \\
\hline & Yes & No & Yes & No & \\
\hline Gastroenteritis (incl. gastritis; $n=58$ ) & 23 & 17 & 10 & 8 & $\chi^{2}=0.01$, d.f. $=1, p>0.05$ \\
\hline Scabies $(n=73)$ & 27 & 16 & 18 & 12 & $\chi^{2}=0.05$, d.f. $=1, p>0.05$ \\
\hline Fever (clinical malaria+ Typhoid; $n=116$ ) & 56 & 30 & 19 & 11 & $\chi^{2}=0.03$, d.f. $=1, p>0.05$ \\
\hline URTI $(n=204)$ & 91 & 67 & 40 & 6 & $\chi^{2}=13.3$, d.f. $=1, p<0.001$ \\
\hline LRTI $(n=44)$ & 11 & 6 & 23 & 4 & $\chi^{2}=1.4$, d.f. $=1, p>0.05$ \\
\hline Abscess $(n=10)$ & 3 & 1 & 5 & 1 & $\chi^{2}=0.2$, d.f. $=1, p>0.05$ \\
\hline Nutritional deficiencies $(n=22)$ & 2 & 9 & 8 & 3 & $\chi^{2}=3.82$, d.f. $=1, p<0.05$ \\
\hline Injuries (incl infected wounds; $n=55$ ) & 22 & 10 & 13 & 10 & $\chi^{2}=0.006$, d.f. $=1, p>0.05$ \\
\hline Diabetics investigated $(n=02)$ & 1 & 0 & 1 & 0 & $\chi^{2}=0.87$, d.f. $=1, p>0.05$ \\
\hline Skin ailments (fungal; $\mathrm{n}=34$ ) & 14 & 7 & 10 & 3 & $\chi^{2}=0.06$, d.f. $=1, p>0.05$ \\
\hline Dermatitis (incl acne; $n=34$ ) & 19 & 3 & 10 & 2 & $\chi^{2}=0.07$, d.f. $=1, p>0.05$ \\
\hline Ophthalmic keratitis $(n=10)$ & 3 & 2 & 4 & 1 & $\chi^{2}=0.00$, d.f. $=1, p>0.05$ \\
\hline Sinusitis $(n=24)$ & 10 & 3 & 9 & 2 & $\chi^{2}=0.04$, d.f. $=1, p>0.05$ \\
\hline Allergic RTI $(n=45)$ & 25 & 10 & 09 & 1 & $\chi^{2}=0.6$, d.f. $=1, p>0.05$ \\
\hline UTI $(n=07)$ & 3 & 1 & 2 & 1 & $\chi^{2}=0.3$, d.f. $=1, p>0.05$ \\
\hline Female RTI and STIs $(n=10)$ & 4 & 1 & 4 & 1 & $\chi^{2}=0.6$, d.f. $=1, p>0.05$ \\
\hline Diarrhea and dysentery $(n=33)$ & 15 & 1 & 14 & 3 & $\chi^{2}=2.3$, d.f. $=1, p>0.05$ \\
\hline \multirow[t]{3}{*}{ Total } & 329 & 184 & 199 & 69 & $\chi^{2}=8.23$, d.f. $=1, p<0.005$ \\
\hline & 513 & & 268 & & \\
\hline & 781 & & & & \\
\hline
\end{tabular}

LRTI: Lower respiratory tract infection; RTI: Reproductive tract infection; STI: Sexually transmitted infection; UTI: Urinary tract infection 
Table 6: Outcome of applying COPC services model from RHTC as compared with primary health care services received from $\mathrm{PHC}[\mathrm{N}=781]$

\begin{tabular}{|c|c|c|c|c|c|c|c|}
\hline \multirow{2}{*}{$\begin{array}{l}\text { Community-oriented primary } \\
\text { care parameters considered }\end{array}$} & \multicolumn{2}{|c|}{$\begin{array}{l}\text { No. of patients satisfied } \\
\text { with primary health care } \\
\text { services by PHC }(n=199)\end{array}$} & \multicolumn{2}{|c|}{$\begin{array}{l}\text { No. of patients satisfied } \\
\text { with COPC services } \\
\text { from RHTC }(n=329)\end{array}$} & \multicolumn{2}{|c|}{ Total } & \multirow[b]{2}{*}{ Chi-square test } \\
\hline & Yes & No & Yes & No & Yes & No & \\
\hline $\begin{array}{l}\text { Socioeconomic impact on } \\
\text { health from services }\end{array}$ & 126 & 73 & 275 & 54 & 401 & 127 & $\chi^{2}=26.7$, d.f. $=1, p<0.0000$ \\
\hline $\begin{array}{l}\text { Cultural determinants of } \\
\text { health identified from services }\end{array}$ & 121 & 78 & 201 & 128 & 322 & 206 & $\chi^{2}=0.0$, d.f. $=1, p>0.05$ \\
\hline $\begin{array}{l}\text { Identification of health needs } \\
\text { from services }\end{array}$ & 137 & 62 & 189 & 140 & 326 & 202 & $\chi^{2}=6.34$, d.f. $=1, p<0.05$ \\
\hline $\begin{array}{l}\text { Participation in health care } \\
\text { services }\end{array}$ & 73 & 126 & 226 & 103 & 299 & 229 & $\chi^{2}=0.0$, d.f. $=1, p<0.000$ \\
\hline
\end{tabular}

our study area of village Shernagar $(47.9 \%)$ indicate that real impact of primary health care services from PHC is questionable. This aspect was also revealed in few studies, ${ }^{8-11}$ which indicate that not only the communicable diseases (contagious, infectious, and waterborne diseases, such as amoebiasis, typhoid, infectious hepatitis, worm infestations, measles, malaria, tuberculosis, whooping cough, respiratory infections, pneumonia, and reproductive tract infections) dominate the morbidity pattern in rural areas, but also noncommunicable diseases, such as cancer, blindness, mental illness, hypertension, diabetes, human immunodeficiency virus/acquired immunodeficiency syndrome, accidents, and injuries are also on the rise among rural people. ${ }^{11}$

Literature also reveals that nearly $70 \%$ of all deaths, and $92 \%$ of deaths from communicable diseases, occurred among the poorest $20 \%$ of the Indian population. ${ }^{11}$ The majority of rural deaths, which are preventable, are due to infections and communicable, parasitic, and respiratory diseases. Infectious diseases dominate the morbidity pattern in rural areas (40\% rural: $23.5 \%$ urban). Waterborne infections, which account for about $80 \%$ of sickness in India, make every fourth person dying of such diseases in the world an Indian. ${ }^{11}$

The literature further reveals that among communicable diseases, URTI (67.06\%) and acute gastroenteritis $(12.55 \%)$ take the maximum burden, whereas musculoskeletal pains $(26.55 \%)$ and hypertension $(15.53 \%)$ are the most reported diseases among noncommunicable diseases. ${ }^{18}$ It has also been seen that although the increasing trend of noncommunicable diseases has been observed, infectious diseases are still more prevalent even in a wellplanned modern city of India like Chandigarh. ${ }^{18}$

In our present study, the sociodemographic dominance of predominant Muslim population in the study area (52.5\%) coupled with only literates $(55.8 \%)$ and enough population belonging to backward castes (SC/ST $\pm \mathrm{OBC}$, $21.6 \%$ explains the significant presence of morbid conditions in our study area just similar to other studies..$^{8-11,18,19}$
Our study findings also corroborate with other studies in the literature, ${ }^{24-26}$ which however suggests that although PHC is the best approach to achieving universal health coverage $e^{24,25}$ and a fundamental requirement for achieving the Sustainable Development Goals, ${ }^{22,24}$ its real positive impact on health status is questionable. Unfortunately, the concept of PHC was created at AlmaAta in 1978, and many countries have failed to establish effective PHC. ${ }^{24,25}$ The PHC is often neglected and diluted into poor quality health care by inadequately resourced, trained, and scarce health workers; or reduced to a series of selected activities and vertical disease-orientated programs. ${ }^{24,25}$ The World Health Report also recommended a number of reforms that are required to establish more effective PHC, thereby improving health equity by focusing on universal coverage, making health systems more people-centered by changing the focus of service delivery, making governance of the system more reliable by developing leadership, and being more community-orientated with a public health perspective. ${ }^{24,25}$

In our present study, the morbidity pattern of primary care diseases in RHTC and PHC area was dominated by upper respiratory infections (26.1\%). In the majority of diseases, patients availed COPC services from RHTC as compared with primary health care services from PHC, and this was statistically significant for morbid conditions of URTI ( $p<0.0001)$ and management of nutritional deficiencies $(p<0.05)$. Our finding thus also corroborates with other studies in the literature. ${ }^{27-33}$

It has been seen that there is a broader scope of application of COPC as seen in a country, such as Bhutan. ${ }^{25}$ The COPC and complementary and alternative medicine are well integrated within the few medical systems, such as Cuban. ${ }^{28}$ Significant efforts are required to overcome the market approach of the national health system, and structural changes to social policies at the national and district level are needed if the PHC strategy is expected to achieve its full potential. ${ }^{29}$ Moreover, COPC has important values and methods to offer disparate but powerful movements 
in public health worldwide. ${ }^{30}$ Coordination by dedicated nonphysician staff is often required to implement COPC concepts in rural practices in underserved areas. ${ }^{31}$

In our present study, it was also found that RHTC services were significantly better as compared with PHC services in terms of socioeconomic impact on health from services $(p<0.0000)$, identification of health needs from services $(p<0.0000)$, and participation in health care services $(p<0.05)$. Our finding corroborates with other studies in literature. ${ }^{17-20,32-37}$ The COPC, which is "a continuous process by which primary health care is provided to a defined community based on of its assessed health needs by the planned integration of public health with primary care practice, ${ }^{\prime 17}$ was also found to be a useful approach in our present study. A COPC practice integrates the care of personal health problems with the community's major health problems by developing promotive, preventive, curative, and rehabilitative programs to target populations. ${ }^{17}$ Studies also indicate that a modified COPC approach which was also used in our present study can be used in general practice and it has more impact at primary care level than at practice level. ${ }^{18}$ Community-oriented primary care seems to be the same combination of public health and general practice perspectives currently sought in the formation of primary care trusts in Britain's National Health Service. 19,20

It has been seen from the studies that COPC allows primary care physicians to expand the range of health care services and their ability to reach out to people. Incorporation in COPC has the potential to make a major contribution in reshaping health care in the United States. ${ }^{19,20}$ By combining personal care with the broader PHC approach, using the tools of COPC, we will build a much more robust and appropriate model of health care for our situation. ${ }^{32}$ It has been seen that although government health facilities were more efficient in the delivery of primary health care services as compared with private training health facilities, ${ }^{33-37}$ RHTCs can be good supporting components to national health programs ${ }^{33-37}$ just similar to the findings of our present study.

We therefore, further suggest a paradigm shift from the current "biomedical model" to a "sociocultural model," which is the need of the hour, should bridge the gaps and improve quality of rural life, address the prevailing inequalities, and work toward promoting a long-term perspective plan mainly for rural health, and is imperative as suggested by other studies in literature. ${ }^{11-20}$

\section{LIMITATIONS}

The comparison parameters for socioeconomic impact of the two models are not standardized. The nonperformance of further correlation of comparison parameters is also a limiting factor in our study. The nonstudied effect of confounders may be a restricting factor in our study. Moreover, our study is based on a small setting at the district level, hence, its generalization should be done with caution.

\section{CONCLUSION}

There is no doubt that the universal health coverage achieved through primary health care is a laudable and important goal, but the quality of this primary health care is not of that level on which the population has trust in the services and gains in health outcomes are clearly seen. Here, COPC can be a good answer provided by RHTCs of budding medical colleges in India to take a leading role in this direction for significantly influencing the morbidity status of rural people as found in our study. Authors, however, recommend more in-depth multicentric studies for actually knowing the real impact of this kind of COPC model in a developing country, such as India.

\section{ACKNOWLEDGMENTS}

Authors would like to thank all the RHTC and PHC Makhiyali staff including the medical officer of the area and medical interns and postgraduates (Dr Rama Shankar, Dr Pradeep Choudhary, Dr Sangeeta Jain Sharma, Dr Tausif Alvi, and Dr Sana Siddique) from the Department of Community Medicine, Muzaffarnagar Medical College, who contributed in data collection to execution in management of this study at both RHTC and PHC.

\section{REFERENCES}

1. WHO. Alma-Ata Declaration; [last updated 2010 Sep 10; cited 2017 March 1]. Available from: http://www.who.int/ publications/almaata_declaration_en.pdf.

2. Primary health care and community oriented primary care: a collaborative, cooperative, and coordinated approach to meeting the health needs of a community; [updated 2010 Sep 10 and cited 2017 March 1]. Available from: http://www. bchealthcouncil.org/Resources/Documents/Primary\%20 Health\%20Care\%20and\%20Community\%20Oriented\%20 Primary\%20Care\%20final.pdf.

3. Gofin J, Gofin R. Community-oriented primary care and primary health care. Am J Public Health 2005 May;95(5):757.

4. Kark SL, Kark E, Abramson JH, Gofin J, editors. Atencion Primaria Orientada a la Comunidad [in Spanish]. Barcelona: Ediciones DOYMA SA; 1994.

5. Nevin JE, Gohel MM. Community-oriented primary care. Prim Care 1996 Mar;23(1):1-15.

6. Tapp H, White L, Steuerwald M, Dulin M. Use of communitybased participatory research in primary care to improve healthcare outcomes and disparities in care. J Comp Eff Res 2013 Jul;2(4):405-419.

7. Prasad S. Morbidity pattern and treatment in India. Ann Trop Med Public Health 2012(5);5:458-467. 
8. Sharma D, Mazta SR, Parashar A. Morbidity pattern and health-seeking behavior of aged population residing in Shimla hills of North India: a cross-sectional study. J Family Med Prim Care 2013 Apr;2(2):188-193.

9. Joseph N, Nelliyanil M, Nayak SR, Agarwal V, Kumar A, Yadav H, Ramuka G, Mohapatra KT. Assessment of morbidity pattern, quality of life and awareness of government facilities among elderly population in South India. J Family Med Prim Care 2015 Jul-Sep;4(3):405-410.

10. Patil AV, Somasundaram KV, Goyal RC. Current health scenario in rural India. Aust J Rural Health 2002;10:129-135.

11. Kamath KR, Feldman RA, Rao SJ, Webb KG. Infection and disease in a group of south Indian families. II. General morbidity patterns in families and family members. Am J Epidemiol 1969 Apr;89(4):375-383.

12. Kumar R, Bahal SP, Srivastava A. Morbidity pattern of geriatric population in rural areas of western Uttar Pradesh. Int J Med Sci Public Health 2016;5(3):430-433.

13. Verma V, Prakash S, Parveen K, Shaikh S, Mishra N. A comparative study of morbidity pattern in elderly of rural and urban areas of Allahabad district, Uttar Pradesh, India. Int J Community Med Public Health 2016;3(5):1152-1156.

14. Kansal S, Kumar A, Singh IJ, Mohapatra SC. A study on morbidity pattern in rural community of eastern Uttar Pradesh. Indian J Prev Soc Med 2008;39(3-4):184-188.

15. Kark, SL.; Kark, E. Promoting community health: from Pholela to Jerusalem. Johannesburg, South Africa: Witwatersrand University Press; 1999.

16. Yadav V, Manjunath SR, Mukherji S, Ramakrishnan TS. Morbidity profile of OPD patients of an urban health and training center: a tool for the health planners. Natl J Community Med 2015;6(2):46-50.

17. Davey S, Raghav SK, Muzammil K, Singh JV, Davey A. Study of rural health centre services utilization by adolescents in district Muzaffarnagar (Uttar Pradesh-India). Int J Med Sci Public Health 2014;3(5):603-606.

18. Goel NK, Dhiman A, Kaalia M, Navpreet S. Magnitude and trend of various diseases at a tertiary care institution in Chandigarh, Northern India. Int J Latest Res Sci Technol 2015;4(2):78-81.

19. Ray SK, Basu SS, Basu AK. An assessment of rural health care delivery system in some areas of West Bengal - an overview. Indian J Public Health 2011 Apr-Jun;55(2):70-80.

20. Goffin J, Foz G. Training and application of communityoriented primary care (COPC) through family medicine in Catalonia, Spain. Fam Med 2008 Mar;40(3):196-202.

21. Mash R, Almeida M, Wong WCW, Kumar R, von Pressentin KB. The roles and training of primary care doctors: China, India, Brazil and South Africa. Hum Resour Health 2015 Dec 4;13:93.

22. Rhyne R, Bogue R, Kukulka G, et al. Communit-Oriented Primary Care: Health Care for the Twenty-First Century. Washington, DC: American Public Health Association; 1998.

23. Longlett SK, Kruse JE, Wesley R M. Community-Oriented Primary Care:Historical Perspective. J Am Board Fam Pract 2001;14:54-63
24. Iliffe S, Lenihan P, Wallace P, Drennan V, Blanchard M, Harris A. Applying community-oriented primary care methods in British general practice: a case study. Br J Gen Pract 2002 Aug;52(481):646-651.

25. Minimum Standard Requirements for the Medical College for 150 admissions annually. Regulations, 1999; [last updated 1999 March 30; cited 2016 Oct 20]. Available from: http://www.mciindia.org/helpdesk/how_to_start/ STANDARD\%20FOR\%20150.pdf.

26. Iliffe $S$, Lenihan $P$. Integrating primary care and public health: learning from the community-oriented primary care model. Int J Health Serv 2003;33(1):85-98.

27. Garr D, Rhyne R, Kukulka G. Incorporating a communityoriented approach in primary care. Am Fam Physician 1993 Jun;47(8):1699-1702.

28. Reid S. Community-oriented primary care: the missing link. Afr J Prm Health Care Fam Med 2010;2(1):260-262.

29. Starfield B, Powe NR, Weiner JR, Stuart M, Steinwachs D, Scholle SH, Gerstenberger A. Costs vs quality in different types of primary care settings. JAMA 1994 Dec 28;272(24): 1903-1908.

30. Tangcharoensathien V, Mills A, Palu T. Accelerating health equity: the key role of universal health coverage in the Sustainable Development Goals. BMC Med 2015;13:101.

31. Nirola DK, Tshering G, Brodie J, Huntington MK. The impact of community-oriented primary care in Trongsa Dzongkhag, Kingdom of Bhutan. Indian J Community Med 2006;31(1):18-23.

32. Dresang LT, Brebrick L, Murray D, Shallue A, Sullivan-VedderS. Family medicine in Cuba: community-oriented primary care and complementary and alternative medicine. J Am Board Fam Pract 2005 Jul-Aug;18(4):297-303.

33. Andrea P, Méndez M. Evaluation of a primary health care strategy implemented in a market oriented health system: the case of Bogota, Colombia. Available from: http://umu. diva-portal.org/smash/get/diva2:705832/FULLTEXT01.pdf.

34. Mullan F, Epstein L. Community-oriented primary care: new relevance in a changing world. Am J Public Health 2002 Nov;92(11):1748-1755.

35. Kukulka G, Christianson JB, Moscovice IS, DeVries R. Community-oriented primary care. Implementation of a national rural demonstration. Arch Fam Med 1994 Jun;3(6): 495-501.

36. Davey S, Raghav SK, Singh JV, Davey A, Singh N. A comparative evaluation of public health centers with private health training centers on primary healthcare parameters in India: a study by data envelopment analysis technique. Indian J Community Med 2015 Oct-Dec;40(4):252-257.

37. Davey S, Raghav SK, Muzammil K, Singh JV, Davey A, Singh SK, Garg G, Sehgal S. Study on role of rural health training centre (RHTC) as a supporting component to a primary health care system for NRHM programme in district Muzaffarnagar (UP). Int J Res Med Sci 2014;2(2):653-661. 